\title{
Robotisering: het kan, maar moet het ook?
}

\author{
Roel Schouteten ${ }^{*}$
}

\section{Vraag}

Het thema robotisering staat de laatste tijd weer erg in de belangstelling. Naar aanleiding van een rapport van de economen Frey en Osborne (2013) hebben twee journalisten van de Volkskrant een analyse gemaakt van de mate waarin beroepen in Nederland gevoelig zijn voor robotisering. Zij komen tot de conclusie dat er heel wat banen op de tocht staan. Ook minister Asscher van Sociale Zaken en Werkgelegenheid (SZW) schetste tijdens een toespraak op een SZW-congres (29 september 2014) een scenario van grote technologische werkloosheid.

In een reeks van artikelen in de Volkskrant werden voorbeelden gepresenteerd van wat robotisering allemaal mogelijk maakt: zelfrijdende auto's, doe-het-zelfbankieren, operatierobots, zelfscannen in de supermarkt. Al deze ontwikkelingen gaan ten koste van banen (chauffeurs, bankmedewerkers, medisch personeel, caissières). Van de andere kant wordt er betoogd dat er ook nieuwe banen worden gecreëerd, zelfs banen waar we nu nog geen idee van hebben. Wat dat betreft, is er eigenlijk weinig nieuws onder de zon, want deze discussies werden in de vorige eeuw ook al gevoerd; alleen heette de rol van technologie toen mechanisering en later automatisering en ICT. De in deze discussies geschetste doemscenario's over massawerkloosheid als gevolg van nieuwe technologie zijn nooit uitgekomen.

Maar ondanks dat de discussies in principe vergelijkbaar zijn, is het opvallend dat er in de huidige populaire discussies nog steeds vooral een technologisch deterministisch perspectief wordt gehanteerd: het is technisch mogelijk, dus zal het gebeuren. Er is weinig oog is voor wat we 'organizational choice' kunnen noemen; keuzeruimte om beslissingen te nemen over de inrichting van het werk. Technologie maakt het mogelijk om het werk op andere, snellere, efficiëntere, goedkopere, minder complexe - of juist complexere - manieren te organiseren. Maar of dat ook daadwerkelijk moet, is een hele andere vraag. Op allerlei niveaus zijn er mogelijkheden om keuzes te maken over of en op welke wijze technologie ingezet kan worden om de productiviteit, en daarmee de welvaart, te verhogen. In de kolommen van TvA is daar in het verleden al aandacht voor geweest, bijvoorbeeld in een themakatern in 2002, een themanummer in 2005, en heel recent nog een column van Joop Schippers in het laatste nummer van 2014. Een belangrijke conclusie daaruit is dat technologie an sich niet bepalend is voor de functiestructuur en daarmee de beroepenstructuur, werkgelegenheid en kwaliteit van de arbeid -

* Roel Schouteten is werkzaam bij de Radboud Universiteit, Faculteit der Managementwetenschappen, en redactielid van het Tijdschrift voor Arbeidsvraagstukken. E-mail: r.schouteten@fm.ru.nl. 
maar de combinatie en afstemming met organisatieontwerpprincipes ('organizational choice'). Over deze keuzemogelijkheden zien we in de populaire discussies weinig terug. In dit opinie- en debatkatern willen we hier verandering in brengen om zo een verdiepende impuls aan de bestaande discussies te geven.

De vraag die we voor dit TvA-debat aan een aantal auteurs hebben voorgelegd, is de volgende: welke keuzes kunnen, mogen of moeten worden gemaakt om, met het oog op werkgelegenheid en kwaliteit van de arbeid, het proces van robotisering in goede banen te leiden? Kun of moet je dit (willen) sturen/reguleren of moet je het aan de markt overlaten? Wat zijn de lessen uit het verleden en gelden die nog steeds?

\section{Antwoorden}

In hun bijdragen leggen de auteurs van dit katern verschillende accenten die als eyeopener aan de huidige discussie kunnen bijdragen. Rinie van Est plaatst de huidige discussie in een historisch en macro-economisch perspectief en legt uit wat er schort aan de analyse van Frey en Osborne. De les die uit deze analyse kan worden getrokken, is dat een goed debat niet alleen gaat over welke menselijke vaardigheden geautomatiseerd kunnen worden, maar ook over (1) de rol van technologie bij het creëren van nieuwe banen, (2) de economische, sociale, ethische en juridische aspecten hierbij, en (3) de wijze waarop IT de organisatie van arbeid verandert. Daarbij gaat het nadrukkelijk om meer vormen van technologie dan alleen robots die fysieke arbeid kunnen overnemen. Van Est sluit af met een aantal relevante vragen over de noodzaak en de mogelijkheden bepaalde waarborgen te creëren voor werknemers die met robotisering (en aanverwante trends) te maken krijgen. Deze vragen moeten het robotiseringsdebat verder brengen dan de doemscenario's die nu de boventoon lijken te voeren.

In de tweede bijdrage schets Lex Borghans drie manieren voor arbeidsmarktbeleid om op de opkomst van robots te reageren. Ook hij baseert zich op een aantal lessen uit het verleden en destilleert daaruit drie mogelijke reacties (aanpassing, bescherming en flexibilisering) en wat daarvan de opbrengsten of gevolgen kunnen zijn, met name in termen van vereiste kennis en vaardigheden. De arbeidsmarkt is flexibel genoeg (gebleken) om bepaalde schommelingen in de vraag naar kennis en specialisten op te vangen, maar soms is de tijd te kort om nieuwe kennis bij getroffen specialisten te bewerkstelligen. In die gevallen moet de maatschappij zich afvragen of het zinvol is om beleid te voeren dat mensen nog flexibeler maakt. De prijs daarvan kan hoog zijn, en de opbrengsten beperkt.

In de derde bijdrage, ten slotte, gaan Jos Benders, Steven Dhondt en Geert Van Hootegem in op de keuzemogelijkheden die organisaties hebben om robots in te zetten en dat het juist de beslissingen omtrent deze keuzes zijn die bepalen wat het niveau van toekomstige banen zal zijn. Ze baseren zich daarbij op het takenpakket-model en de moderne sociotechniek. Daar waar Frey en Osborne zich baseren op beroepen (die verloren zouden gaan), bestuderen deze onderzoekstradities taken die door mensen moeten worden gedaan en hoe die tot functies of beroepen gegroepeerd worden. De belangrijkste vraag om na te gaan welke gevol- 
gen verdergaande robotisering heeft, is dan hoe mensen met technologie omgaan. Keuzes in de inzet van technologie en beslissingen over hoe menselijke taken tot functies worden gecombineerd, bepalen de kwalitatieve structuur van de werkgelegenheid. Beleidsmatig betekent dit dat er bewust moet worden nagedacht over ontwerpmogelijkheden. Daartoe is het van belang het onderzoek op dit terrein verder uit te breiden.

\section{Lessen}

De bijdragen in dit katern laten zien dat de huidige discussies, met name in de populaire media, een inhoudelijke nuanceringsimpuls nodig hebben. Alle drie de bijdragen wijzen erop dat door andere vragen te stellen en andere perspectieven te hanteren er een meer genuanceerd debat kan worden gevoerd over de mogelijke effecten van toenemende robotisering en manieren om daarmee om te gaan, zowel op beleidsniveau als op het niveau van organisaties en individuele werknemers. En debat is nodig, want lessen uit het verleden leren dat het doen van voorspellingen over de wisselwerking tussen technologie en arbeid lastig is. Het debat zou niet alleen moeten kijken naar de directe invloed van technologie op arbeid, en dus welke arbeid door technologie kan worden overgenomen. Er zijn (keuze)mogelijkheden voor verschillende partijen om de uitkomsten van robotisering mede te bepalen. De overheid en sociale partners kunnen nadenken over het waarborgen van de belangen van werknemers: hoe en door wie kunnen waarborgen worden ingebouwd in beleid en afspraken? Deze partijen kunnen ook nadenken over de noodzaak en wenselijkheid van verdere flexibilisering van de arbeidsmarkt: kun je de arbeidsmarkt zover flexibiliseren dat alle mogelijke schommelingen in de vraag naar kennis en vaardigheden kunnen worden opgevangen? En tegen welke prijs? Voor organisaties (bestuurders, managers) ligt er de uitdaging na te denken over welke keuzes er gemaakt kunnen worden in het gebruik van technologie en de creatie van kwalitatief goede arbeidsplaatsen.

Onderzoek (arbeidsmarktonderzoek, organisatiesociologisch onderzoek, beleidsonderzoek) kan in deze debatten een ondersteunende rol spelen door het leveren van verantwoorde analyses. De verschillende perspectieven in de bijdragen in dit katern laten zien dat het combineren daarvan (in multidisciplinair onderzoek en debat) interessante inzichten oplevert die het debat verder kunnen brengen. Daarmee kunnen we afstand nemen van de doemscenario's (en het bijbehorende lijdzaam afwachten) en grijpen we de kans meer zelf mede te bepalen hoe technologie en arbeid elkaar (indirect via menselijk handelen) beïnvloeden.

\section{Literatuur}

Asscher, L. (2014). Robotisering: Kansen voor morgen. Den Haag: Ministerie van Sociale Zaken en Werkgelegenheid. http://www.rijksoverheid.nl/documenten-en-publicaties/ toespraken/2014/09/29/robotisering-kansen-voor-morgen-toespraak-van-ministerasscher-tijdens-het-szw-congres-op-29-9-2014.html 
Frey, C.B. \& Osborne, M.A. (2013). The future of employment: How susceptible are jobs to computerization? Oxford: Martin Publication.

Schippers, J. (2014). Column: De robots zijn welkom, mits... Tijdschrift voor Arbeidsvraagstukken, 30(4), 350-352. 